\title{
Apis mellifera pollination improves agronomic productivity of anemophilous castor bean (Ricinus communis)
}

\author{
RÔMULO A.G. RIZZARDO ${ }^{1}$, MARCELO O. MILFONT ${ }^{1}$, EVA M.S. DA SILVA ${ }^{1,2}$ and BRENO M. FREITAS ${ }^{1}$ \\ ${ }^{1}$ Universidade Federal do Ceará, Departamento de Zootecnia, CCA, Bloco 808, \\ Campus Universitário do Pici, Av. Mister Hull, s/n, 60356-000 Fortaleza, CE, Brasil \\ ${ }^{2}$ Fundação Universidade Federal do Vale do São Francisco, Coordenação do Colegiado Acadêmico de Zootecnia, \\ Campus Ciências Agrárias, Rodovia BR 407, km 12, Lote 543, \\ Projeto de Irrigação Senador Nilo Coelho, s/n, “C1”, 56300-990 Petrolina, PE, Brasil
}

Manuscript received on September 9, 2011; accepted for publication on June 1, 2012

\begin{abstract}
Castor bean (Ricinus communis L.) is cultivated mainly for biodiesel production because of its oil-rich seeds; it is assumed to be an anemophylous species. But pollination deficit can lead to low productivity often attributed to other reasons. In this paper, we investigated pollination requirements, pollination mechanism, occurrence of pollination deficit, and the role of biotic pollinators in a large commercial plantation of castor bean. Our results show that $R$. communis bears a mixed breeding system favoring selfing by geitonogamy, although the wind promotes mostly outcrossing. We also found that the honey bee (Apis mellifera L.) foraging on castor bean can both transfer pollen from male to female flowers within the same raceme and boost the release of airborne pollen by male flowers. Both situations increase geitonogamy rates, raising significantly fruit set and seed yield. This is the first report of an animal foraging activity increasing seed yield in an anemophilous and geitonogamous crop and elucidates the role of biotic pollinators in castor bean reproduction.
\end{abstract}

Key words: oleaginous crop, pollination deficit, pollination requirements, seed yield, wind insectassisted pollination.

\section{INTRODUCTION}

The castor bean (Ricinus communis L.) is an oil crop originated from Africa and now cultivated worldwide (FAOSTAT; http://faostat.fao.org/site/339/). Since ancient times it has been exploited for its oil which was used as ingredient to cosmetics, shampoo, soap, hand lotion, laxative, fuel for lamps and as a high speed lubricant (Capasso et al. 1994, Copley et al. 2005, Morris et al. 2011). Nowadays, castor bean is cultivated mainly for biodiesel production because

Correspondence to: Breno Magalhães Freitas

E-mail: freitas@ufc.br the oil content of its seeds reach up to 50\% (Melo et al. 2008, Sailaja et al. 2008, Vanaja et al. 2008).

In 2009, the average castor bean yield varied considerably from $1,307.1$ and $904.7 \mathrm{~kg}$ seeds/hectare (ha $=100$ acres) in India and China, respectively, to only $567.7 \mathrm{~kg}$ seeds/ha in Brazil (FAOSTAT; http:// faostat.fao.org/site/567/). In India, Kumar et al. (1997) observed that moisture, thermal and photoperiodic regimes influenced castor bean productivity. Experiments carried out in Brazil have shown yield potential over $1,500 \mathrm{~kg}$ seeds/ha to many varieties, but water shortage, pest damages, lack of soil preparation and 
inadequate crop management have been blamed for low productivity in a subsistence-based agriculture relying on erratic rainfall (Holanda-Neto et al. 2002, Severino et al. 2006a, b). Growers try to compensate low productivity enlarging the planted area at the expenses of native vegetation (Rizzardo et al. 2008).

Castor bean is a monoecious species whose male flowers bear hundreds of explosive anthers and because the floral traits of the species suggest wind pollination it is assumed to be an exclusively anemophylous species (Weiss 1971, Bianchini and Pacini 1996), and there has been no further investigation on the crop breeding system, pollination mechanism, occurrence of pollination deficit and the role of biotic pollinators. However, the syndrome concept compiled by Fægri and van der Pijl (1979) has been contested recently (e.g. Waser et al. 1996, Gómez and Zamora 1999). Plants presenting pollination syndrome by an animal group can be actually pollinated by other (Pacheco Filho et al. 2011) while plants that are often wind pollinated can have improved seed and fruit set when animal pollinators are also involved (Sadakathulla 1991, Listabarth 1992, Meléndez-Ramirez et al. 2004).
Castor bean is an excellent source of nectar to the honey bee (Apis mellifera L.) and workers visit the racemes for both pollen and extrafloral nectar (Milfont et al. 2009). This behavior may favor pollen transfer between male and female flowers and this bee species may play some role in castor bean pollination.

Therefore, this paper aimed to investigate the castor bean pollination requirements, its pollination mechanisms and the role of wind and the honey bee to the pollination of this crop.

\section{MATERIALS AND METHODS}

\section{STUDY AREA}

The work was carried out in a 3,150 ha castor bean commercial plantation, BRS 149 -Nordestina, belonging to the Núcleo de Produção Comunitária Santa Clara (NPCSC) situated at $08^{\circ} 08^{\prime} 32.4^{\prime \prime}$ S and $43^{\circ} 27^{\prime} 12.9^{\prime \prime} \mathrm{W}, 441 \mathrm{~m}$ above sea level, in the county of Canto do Buriti, state of Piauí, Brazil. The plantation occupies 18 fields of 175 ha each and the experiments were set in two 43.75 ha areas within field U (Fig. 1). Observations were taken from May to June 2006 and the following experiments were carried out:

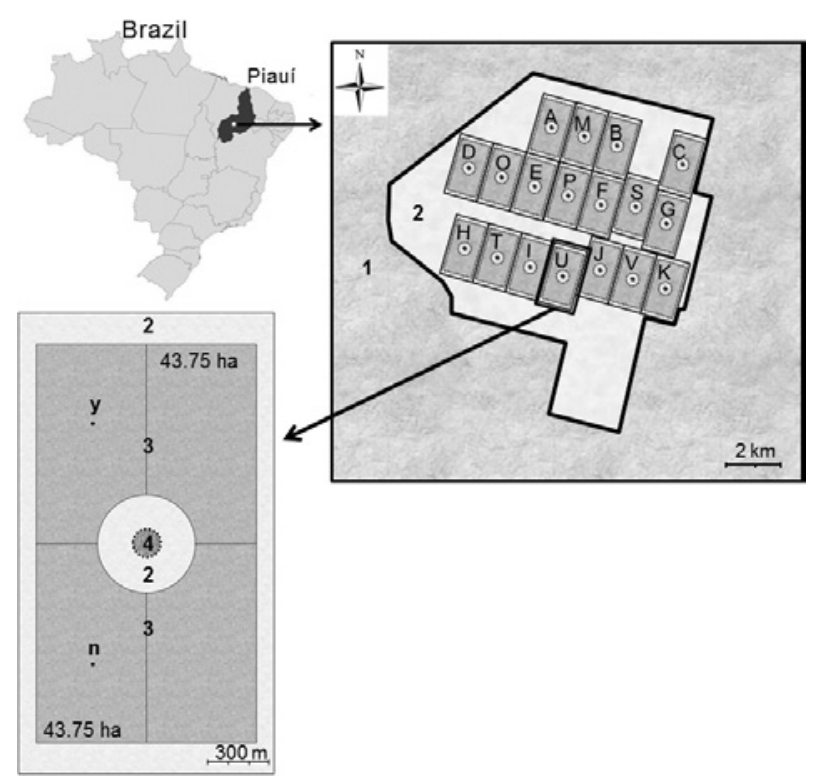

Fig. 1 - Map of Brazil showing the state of Piauí (shaded), where experiments with castor bean were carried out, and the Núcleo de Produção Comunitária Santa Clara (NPCSC) farm on the right: (1) Primary forest; (2) Arable land. Details of the experimental field U and the areas with (y) and without (n) introduction of honey bee (Apis mellifera) colonies are shown in the lower left: (3) Castor bean field; (4) Workers' village. 
Floral DisPlay OF CASTOR BEAN AND Foraging BEHAVIOR OF APIS MELLIFERA L.

The floral display of 100 castor bean racemes were observed throughout their life, as well as the presence of male and female flowers, their proportional number in relation to each other, position and arrangement in the racemes, rewards offered to flower visitors and actual visitation.

Due to the enormous size of the areas cultivated with castor bean and consequent distance to natural vegetation (Fig. 2a), wild floral visitors were almost nonexistent and the honey bee foraging behavior was only possible after introducing eight colonies nesting in Langstroth hives in the center of one of the 43.75 ha area within field U. Seven days later, the number of pollen and nectar collectors visiting 50 inflorescences in five $30 \mathrm{~m}$-long transects set 40 to $60 \mathrm{~m}$ around the colonies were counted and their behavior recorded at 7:00, 9:00, 11:00, 13:00, 15:00 and 17:00 h. This procedure was repeated again four times at seven day intervals.

Pollination REQuirements of CASTOR BEAN AND POLLINATION EFFICIENCY OF APIS MELLIFERA L.

Aiming to know the pollination requirements of the castor bean plant and the role of wind and honey bee in the pollination of $R$. communis, the following treatments were applied during the crop flowering period:

a) Open with no bee introduction: In the other 43.75 ha area, in which honey bee colonies were not introduced, 60 buds of female flowers were randomly chosen in various racemes and marked with cotton thread at their pedicel. After that, the plants were marked with bright colored tags representing this treatment and making easier to find them afterwards. These buds were followed for the next 15 days until the flowers withered and fell or the fruits set. The aim of this treatment was to know the actual fruit set in the area. b) Bagged with muslin bag: In this treatment the same procedure describe above was repeated, except that 327 buds were marked and the whole raceme was covered with $\varnothing 0.1 \mathrm{~cm}$ mesh muslin bags to test the role of the wind in castor bean pollination. Care was taken to prevent the bags touching flowers and interfering with the natural fruit set;

c) Bagged with paper bag: Similar to the treatment above, but marking 127 buds and covering the whole raceme with paper bags to prevent wind or biotic pollination. Again, care was taken to prevent the bags touching flowers and interfering with the natural fruit set;

d) Emasculated and bagged with paper bag: Same as item "c", except that 23 female flowers were marked and racemes were emasculated before bagging them with the paper bags. This treatment aimed to check if castor bean flowers could set fruits without pollination;

e) Hand cross pollination: In this treatment, racemes were emasculated and covered with paper bags until female flowers were well open and with their stigmas elongated. Then, 82 female flowers were manually pollinated with pollen from male flowers of a different plant and rebagged to prevent other pollen grains reaching their stigmas;

f) Hand geitonogamy: Same as item "e", except that 75 female flowers were hand pollinated with pollen from male flowers of the same plant;

g) Open with bee introduction: Similar to item "a", except that this treatment was set in the 43.5 ha area where 8 honey bee colonies were introduced and 47 female flowers were marked approximately $60 \mathrm{~m}$ to the hives.

In all treatments, data to quantify fruit set was taken 15 days after buds/flowers had been manipulated and fruits and seeds were harvested 90 days after pollination took place.

\section{DATA ANALYSES}

Regarding honey bee foraging behavior, the mean numbers of pollen and nectar gatherers were 
calculated and regression curves were estimate to know the daily foraging pattern of both pollen and nectar collectors on castor bean inflorescences.

Data from the pollination treatments were analyzed using Mann-Whitney non-parametric test due to their binomial character ( $\operatorname{set}=1$, not set $=0$ ).

\section{RESULTS}

Floral DisPlay of CASTOR BEAN AND Foraging BeHAVIOR OF APIS MELLIFERA L.

Castor bean flowers were arranged in terminal racemes. Male flowers appeared in the basal and median portions of the raceme, covering approximately two-thirds of the inflorescence, while female flowers were found in the apical part of the raceme, representing approximately one-third of it (Fig. 2b). Male castor bean flowers produced great amounts of pollen, but no nectar. Female flowers also did not produce any nectar. All castor bean nectar was produced by extrafloral nectaries found at junctions of the plant, including on the base of each flower pedicel (Fig. 2c) making racemes the parts of the plant with greater concentration of extrafloral nectaries and the most visited by nectar collectors.

Honey bee workers foraged on castor bean for both pollen and nectar all day long. Early in the morning, the number of bees collecting pollen was similar to those collecting nectar. While the number of nectar gatherers presented a quadratic curve (y $\left.=-0.73 \mathrm{x}^{2}+5.51 \mathrm{x}-2.69, \mathrm{R}^{2}=0.93\right)$, increasing slowly from 7:00 to 13:00 $\mathrm{h}$. and decreasing towards 17:00 h., the pollen gatherers best fitted a fourth power equation $\left(\mathrm{y}=-1.21 \mathrm{x}^{4}+18.23 \mathrm{x}^{3}-94.94 \mathrm{x}^{2}+\right.$ $\left.194.60 \mathrm{x}-112.51, \mathrm{R}^{2}=0.94\right)$ raising steadily from 7:00 h. to a peak by 9:00 h. before decrease towards to the hottest time of the day $(13: 00 \mathrm{~h}$.) to increase again and peak once more by 16:00 h. and, then decrease definitely (Fig. 3).

Pollen collectors visited only male flowers. They landed on the open flowers and scrabble the anthers actively throwing pollen on their own bodies before hovering above the flowers while combing themselves and packing the pollen in their corbiculae (Fig. 2d). After that, they landed again on the flowers and restarted the process or flew away to other raceme or back to the nest.

Flowers did not dehisce all their hundreds anthers simultaneously, but the bees attempted to collect pollen from dehisced anthers allowing them to touch closed anthers and trigger their explosive dehiscence, releasing a great amount of pollen both direct on the bees' bodies and airborne around the insect and raceme (Fig. 2e). Naive bees soon learned how to trigger anthers and harvest their pollen load quicker.

Nectar collectors landed at any part of the racemes, but frequently close to the base where male flowers were produced. Once there, the bees pushed their bodies among the close-packed flowers to reach the extrafloral nectaries situated on the pedicels. In doing that, they rubbed against anthers and may both acquired pollen from dehisced anthers and triggered the explosive dehiscence in those not dehisced yet (Fig. 2f). After reaching the extrafloral nectaries, the bees collected nectar and repeated the process moving in the racemes toward its apices. In the portion of the racemes with female flowers, nectar collectors walked over the long stigmas and rubbed their bodies against them when pushing their bodies through the flowers (Fig. 2g, h).

PolLINATION REQUIREMENTS OF CASTOR BEAN AND

POLLINATION EFFICIENCY OF APIS MELLIFERA L.

There were significant differences $(\mathrm{p}<0.05)$ between pollination treatments (a-g) (Table I). The treatments hand geitonogamy and open with the introduction of honey bee colonies presented the highest fruit set, over $90 \%$, and did not differ ( $p>0.05$ ) from each other (Table I). However, they differed significantly $(p<0.05)$ to all the other treatments.

The second highest fruit setting was achieved by the treatments in which flowers were hand 


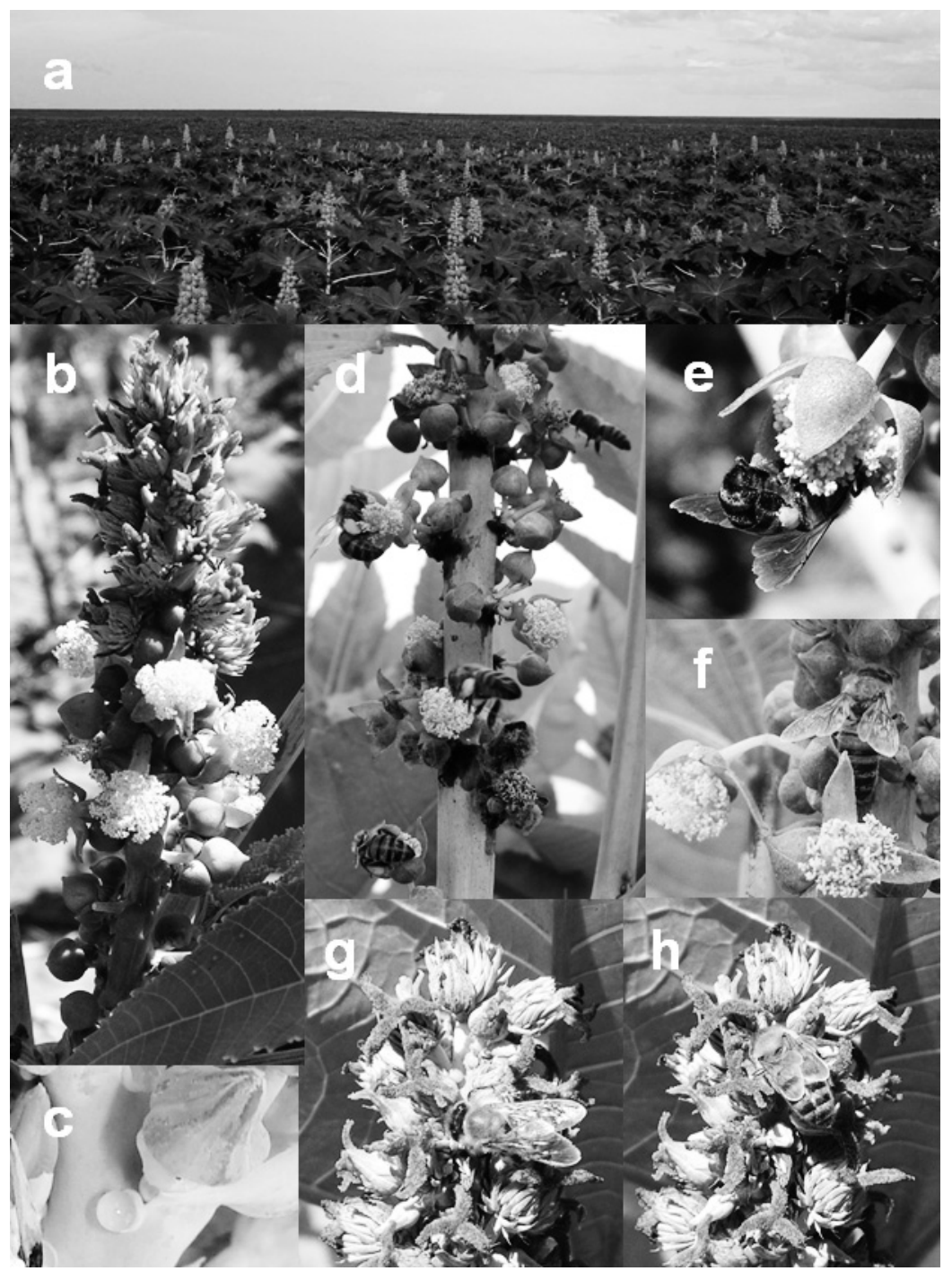

Fig. 2 - Castor bean (Ricinus communis L.) floral display and honey bee (Apis mellifera L.) foraging behavior: (a) castor bean experimental site; (b) male flowers in the lower and female flowers in the upper portion of the inflorescence; (c) extrafloral nectaries situated at the base of a flower pedicel; (d) pollen gatherers harvesting pollen from male flowers; (e) worker scrabbling and trigging the explosive anthers release airborne pollen; (f) nectar gatherer moving from male to female flowers; (g) nectar gatherer walking over stigmas of female flowers; (h) nectar gatherer touching stigmas while pushing through female flowers to reach extrafloral nectaries.

cross pollinated, under open pollination without the introduction of Apis mellifera colonies or bagged with muslin bag (Table I). These treatments did not differ $(p>0.05)$ among them, but differed significantly $(p<0.05)$ to the treatment that flowers were bagged with paper bags. Finally, the treatment where flowers were emasculated and bagged with paper bags did not set any fruit and was not considered to statistical analysis (Table I).

Due to a year with rains $33.7 \%$ below the historical mean to the region (provided by Brazilian Ministry of Agriculture, Livestock and Food Supply, [www.agritempo.gov.br/modules.php?name= Mapas\&estado=PI]), seed yield was well below the 


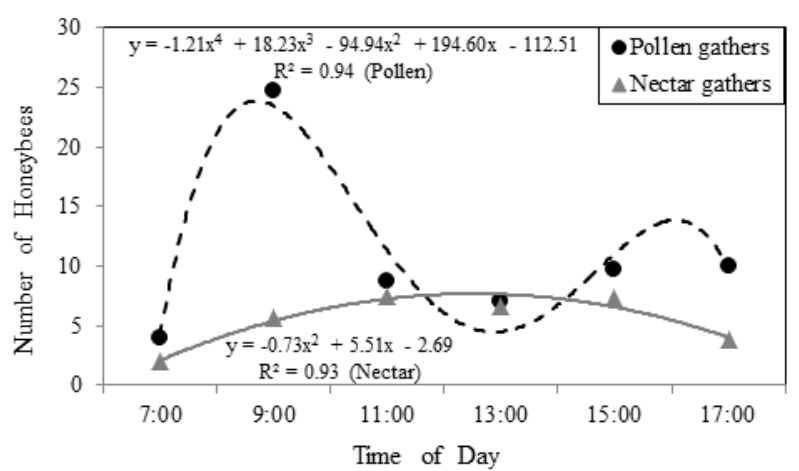

Fig. 3 - Daily pattern of Apis mellifera pollen and nectar gathers foraging on a castor bean (Ricinus communis L.) commercial plantation in Northeast Brazil.

average to the region (440 $\mathrm{kg}$ seed/ha). The area in which colonies of $A$. mellifera were introduced produced $389.35 \mathrm{~kg}$ seeds/ha while that without honey bee introduction only $298.10 \mathrm{~kg} / \mathrm{ha}$. Even low, the yield in the area with honey bee hives was 90.35 $\mathrm{kg}$ seeds/ha $(30.61 \%)$ significantly $(\mathrm{p}<0.05)$ greater than in the area with no hives.

TABLE I

Fruit set of castor bean (Ricinus communis L.) flowers in response to seven pollination treatments: hand cross pollination, hand geitonogamy pollination, open pollination with and without the introduction of Apis mellifera colonies, bagged with muslin bag, bagged with paper bag and emasculated and bagged with paper bag.

\begin{tabular}{cccc}
\hline Treatments & $\begin{array}{c}\text { Number of } \\
\text { flowers }\end{array}$ & $\begin{array}{c}\text { Number of } \\
\text { fruits set }\end{array}$ & $\begin{array}{c}\text { Fruit } \\
\text { set }(\%)\end{array}$ \\
\hline $\begin{array}{c}\text { Hand geitonogamy pollination } \\
\text { Open pollination with } \\
\text { the introduction of } \\
\text { Apis mellifera colonies }\end{array}$ & 75 & $74 \mathrm{a}$ & 99 \\
$\begin{array}{c}\text { Hand cross pollination } \\
\text { Open pollination without } \\
\text { the introduction of }\end{array}$ & 82 & $66 \mathrm{~b}$ & 80 \\
$\begin{array}{c}\text { Apis mellifera colonies } \\
\text { Bagged with muslin bag }\end{array}$ & 327 & $259 \mathrm{~b}$ & 79 \\
$\begin{array}{c}\text { Bagged with paper bag } \\
\text { Emasculated and bagged } \\
\text { with paper bag }\end{array}$ & 124 & $19 \mathrm{c}$ & 15 \\
\hline
\end{tabular}

Values followed by the same letters do not differ at $(\mathrm{p}>0.05)$.

\section{DISCUSSION}

Racemes emasculated and protected by paper bags did not set any fruit and showed that the castor bean is not an apomictic species and cannot set fruits without pollination. However, the treatment which flowers were bagged with paper bags but not emasculated produced around 15\% fruit set showing that the presence of male flowers inside the bags is enough to set some fruits, although in a much lower proportion than when the racemes are unbagged or hand manipulated. Fruit set observed in these bagged racemes is probably due to the explosive nature of castor bean anthers, as described in the literature (Bianchini and Pacini 1996). In such a situation, pollen thrown in the air inside the bag due to the explosion of the anthers may reach some female flowers locate in the lower portion of the raceme, close to the male flowers. As a matter of fact, fruits set in the racemes bagged with paper bags were only in the lower portion of the racemes.

Fruit set in paper-bagged racemes also showed that castor bean flowers in a raceme can autopollinate and set fruits by geitonogamy. Although cross pollination is reckon to be favored in most plant species and set better fruits and more vigorous seeds, mixed breeding systems, in which plants use outcrossing and autogamy or even all three breeding systems (outcrossing, autogamy and apomixis), are not uncommon (Brown et al. 1989). Indeed, castor bean set fruits both under cross- and self-pollination proving to bear a mixed breeding system. But results from the hand geitonogamy treatment producing the highest fruit set indicates that the castor bean is primarily autogamous and because the flowers are unisexual, geitonogamy is the only mean for selfing. Other authors have reported on the autogamy of castor bean (Foster et al. 2010).

The main pollinating agent of castor bean flowers seem to be the wind, since marked flowers in racemes bagged with muslin bags set statistically the same as flowers in racemes open to floral 
visitors in the area with no introduction of honey bee colonies, demonstrating that floral visitors occurring naturally in the area were not relevant to castor bean pollination. This finding is in accordance with the literature that reports $R$. communis as an anemophylous species (Weiss 1971, Bianchini and Pacini 1996, Morris et al. 2011).

Even favoring geitonogamy, castor bean flowers can also set flowers by cross pollination, although in a significantly lower proportion than by selfing, but similar to the open racemes in the area without honey bee introduction and those covered with muslin bags and pollinated by the wind. According to Vogler and Kalisz (2001), selfing breeding system is widespread in anemophylous plant species and wind-pollinated species are either highly selfing or highly outcrossing. Our results show clearly that the wind could not maximize fruit production as hand geitonogamy did, and its similar fruit set to that obtained by hand cross-pollination is certainly because the wind promoted mainly cross pollination rather than geitonogamy. Actually, the castor bean floral arrangement with female flowers situated above male flowers in the racemes favors pollen dispersion for cross pollination (Ramprasad and Bandopadhyay 2010). Although the role of wind in castor bean pollination has already been well established, this pollination mechanism - leading to the prevalence of cross pollination despite the preference for geitonogamy in this species - had not been reported yet. Nevertheless, mixed breeding system with predominance of self-fertilization has been reported to other wind-pollinate species in the literature (Karasawa et al. 2007).

The introduction of honey bee colonies to castor bean plantations produced $17 \%$ increment in fruit set reaching a figure equivalent to that of hand geitonogamy and maximizing fruit set in this crop. It also produced augments of $30.61 \%$ in seed yield per hectare. This result also confirm the occurrence of pollination deficit, as defined by Vaissière et al. (2011), in the area studied. It also indicates that
A. mellifera bees can promote the transference of pollen grains from male to female flowers of the same or adjacent racemes when foraging for pollen and extrafloral nectar in R. communis. The pollination of this anemophylous species mediated by honey bees can take place in two manners: i) worker nectar collectors crawling over and among male flowers to reach the extrafloral nectaries located on the base of each flower's pedicel acquire pollen grains on their bodies and deposit them on the stigmas of female flowers as they move foraging towards the terminal end of the raceme (active pollination); ii) worker pollen collectors scrabbling for pollen on the anthers of male flowers trigger them to explode and release simultaneously a much greater amount of airborne pollen per time unit than usually occurs without the bees aid (passive pollination). This much larger amount of airborne pollen around the raceme may increase considerably the chance that self-pollen grains reaches the stigmas of female flowers of the same or neighboring raceme, rather than cross pollen blown by the wind. Geitonogamy pollination by insect, including honey bee, due to movements up and down in racemes/inflorescences has been documented in the literature to other plant species (Barrett et al. 1994, Meléndez-Ramirez et al. 2004, Jordan and Harder 2006, Narbona and Dirzo 2010) and wind insectassisted pollination has been suggested by various authors to different crops (Free and Ferguson 1983, Mamood and Schmidt 1991, Vaissière et al. 1996) and demonstrated to take place in oilseed rape (Brassica napus), an entomophilous crop (Pierre et al. 2010). This paper is the first report of an animal foraging activity increasing seed yield in an anemophilous and highly geitonogamous plant species, and elucidates the role of biotic pollinators in castor bean.

It also demonstrates that it is possible to increase yield and profitability in this crop using managed pollinators rather than expanding the planted area, even in an adverse year for agriculture. Integration of this knowledge with better agricultural practices could contribute to raise the low productivity 
of castor bean, as demonstrated to cashew nut (Anacardium occidentale) also in Northeast Brazil (Holanda-Neto et al. 2002).

\section{ACKNOWLEDGMENTS}

The authors thank two anonymous referees for their substantial contribution to this paper, the Banco do Nordeste do Brasil (BNB/ETENE/FUNDECI), Fundação Cearense de Apoio ao Desenvolvimento Científico e Tecnológico do Estado do Ceará(Funcap) and Conselho Nacional de Desenvolvimento Científico e Tecnológico (CNPq-Brasília/Brazil) for financial support, M.Sc. and D.Sc. scholarships and a research grant to B.M. Freitas (\#305062/2007-7), respectively. We also acknowledge Brasil Ecodiesel S.A. for allowing the use of its farm, facilities and logistic support during field work.

\section{RESUMO}

A mamoneira (Ricinus communis L.) é cultivada principalmente para produção de biodiesel devido ao alto teor de óleo de suas sementes e considerada como sendo de polinização anemófila. Mas déficits de polinização podem levar a baixos índices de produtividade geralmente atribuídos a outros fatores. Neste trabalho foram investigados os requerimentos, mecanismos e déficit de polinização e o papel dos polinizadores bióticos em um monocultivo comercial de mamona. Os resultados mostram que $R$. communis possui um sistema de polinização misto, favorecendo a autopolinização por geitonogamia, embora o vento normalmente promova polinização cruzada. Observou-se também que a abelha melífera (Apis mellifera L.) forrageando na mamoneira pode tanto transferir pólen das flores estaminadas para as pistiladas do mesmo racemo, quanto aumentar consideravelmente a liberação de pólen em suspensão no ar pelas flores estaminadas. Ambas as situações elevam a taxa de geitonogamia, aumentando significativamente o vingamento de frutos e produção de sementes. Este é o primeiro relato da atividade de forrageio de um animal aumentando a produção de sementes em uma cultura anemófila e de polinização predominantemente por geitonogamia e esclarece o papel dos polinizadores bióticos na polinização da mamoneira.

Palavras-chave: oleaginosas, déficit de polinização, requerimentos de polinização, produção de sementes, polinização anemófila assistida por inseto.

\section{REFERENCES}

BARRET SCH, HARDER LD AND COLE WW. 1994. Effects of flower number and position on self-fertilization in experimental populations of Eichhornia paniculata (Pontederiacea). Funct Ecol 8: 526-535.

BIANCHINI M AND PACINI E. 1996. Explosive anther dehiscence in Ricinus communis L. involves cell wall modifications and relative humidity. Int J Plant Sci 157: 739-745.

BRown AHD, Burdon JJ AND JAROSz AM. 1989. Isozyme analysis of plant mating systems. In: Soltis DE and Soltis PS (Eds), Isozymes in Plant Biology, Portland: Dioscorides Press, Oregon, USA, p. 73-86.

Capasso F, Mascolo N, IzZO AA AND Gaginella TS. 1994. Dissociation of castor oil-induced diarrhoea and intestinal mucosal injury in rat: effect of $\mathrm{N}^{\mathrm{G}}$-nitro-L-arginine methyl ester. Br J Pharmacol 113: 1127-1130.

Copley MS, Bland HA, Rose P, HorTON M AND Evershed RP. 2005. Gas chromatographic, mass spectrometric and stable carbon isotopic investigations of organic residues of plant oils and animal fats employed as illuminants in archaeological lamps from Egypt. Analyst 130: 860-871.

FÆGRI K AND VAN DER PIJL L. 1979. The principles of pollination ecology, $3^{\text {rd }}$ ed., Oxford: Pergamon press, $244 \mathrm{p}$.

Foster JT, Allan GJ, CHAN AP, RABINOWICZ PD, RAVEL J, JACKSON PJ AND KEIM P. 2010. Single nucleotide polymorphisms for assessing genetic diversity in castor bean (Ricinus communis). BMC Plant Biol 10: 13.

FREE JB AND FERGUSON AW. 1983. Foraging behaviour of honeybees on oilseed rape. Bee World 64: 22-24.

GÓMEZ JM AND ZAMORA R. 1999. Generalization vs. specialization in the pollination system of Hormathophylla spinosa (Crucifera). Ecology 80: 796-805.

Holanda-Neto JP, Freitas BM, Bueno DM AND ARAúJo ZB. 2002. Low seed/nut productivity in cashew (Anacardium occidentale): Effects of self-incompatibility and honey bee (Apis mellifera) foraging behaviour. J Hortic Sci Biotech 77: 226-231.

JORDAN CY AND HARDER LD. 2006. Manipulation of bee behavior by inflorescence architecture and its consequence for plant mating. Am Nat 167: 496-509.

KarasaWa MMG, Vencovsky R, Silva CM, ZuCCHI MI, Oliveria GCX AND Veasey EA. 2007. Mating system of Brazilian Oryza glumaepatula populations studied with microsatellite markers. Ann Bot-London 99: 245-253.

KUMAR PV, RAMAKRISHNA YS, RAMANA RAO BV, VICTOR US, SRIVASTAVA NN AND SUBbA RAO AVM. 1997. Influence of Moisture, thermal and photoperiodic regimes on the productivity of castor beans (Ricinus communis L.). Agr Forest Meteorol 88: 279-289. 
ListABARTH C. 1992. A survey of pollination strategies in the Bactridinae (Palmae). Bull Inst Fr Étud Andin 21: 699-714.

MAMOOD AN AND SCHMIDT JO. 1991. Pollination and seed set in pearl millet by caged honey bees (Hymenoptera: Apidae). Bee Sci 1: 151-154.

MElÉNDEZ-RAmireZ V, PARRA-TABla V, KEVAN PG, RAmíREZMorillo I, Harries H, FERnÁNDEZ-BARRERA M AND ZIZUMBO-VILLAREAL D. 2004. Mixed mating strategies and Pollination by insects and wind in coconut palm (Cocos nucifera L. (Arecaceae)): importance in production and selection. Agric For Entomol 6: 155-163.

Melo WC, SAntos AS, SANTA ANNA LMM AND PEREIRA JR N. 2008. Acid and enzymatic hydrolysis of the residue from Castor Bean (Ricinus communis L.) oil extraction for ethanol production: detoxification and biodiesel process integration. J Brazil Chem Soc 19: 418-425.

Milfont MO, Freitas BM, RizZARdo RAG AND Guimarães MO. 2009. Produção de mel por abelhas africanizadas em plantio de mamoneira. Cienc Rural 39: 1206-1211.

Morris JB, WANG ML AND MorSE SA. 2011. Ricinus. In: Kole C (Ed), Wild Crop Relatives: Genomic and Breeding Resources - Oilseeds, Berlin, Heidelberg: Springer Berlin Heidelberg, Germany, p. 251-260.

NARBONA E AND DiRzo R. 2010. A reassessment of the function of floral nectar in Croton suberosus (Euphorbiaceae): a reward for plant defenders and pollinators. Am J Bot 97: 672-679.

PACHECO FILHO AJS, WeSTERKAMP C AND FREITAS BM. 2011. Ipomea bahiensis pollinators: Bees or butterflies? Flora 206: 662-667.

Pierre J, Vaissière BE, Vallée P AND Renard M. 2010. Efficiency of airborne pollen released by honeybees foraging on pollination in oilseed rape: a wind insectassisted pollination. Apidologie 41: 109-115.

RAMPRASAD R AND BANDOPADHYAY R. 2010. Future of Ricinus communis after completion of the draft genome sequence. Curr Sci India 99: 1316-1318.

RizzARdo RAG, Freitas BM, Milfont MO AND Silva EMS. 2008. A polinização de culturas oleaginosas com potencial para produção de biodiesel: um estudo de caso com a mamona (Ricinus communis L.). In: ENCONTRO SOBRE ABELHAS, 8, Ribeirão Preto Proceedings ...., Ribeirão Preto: Funpec, p. 72-79.
SADAKATHULLA S. 1991. Evaluation of honey bee visits on coconut genotypes. Cocos 9: 47-50.

Sailaja M, TARAKESWARI M AND Sujatha M. 2008. Stable genetic transformation of castor (Ricinus communis L.) via particle gun-mediated gene transfer using embryo axes from mature seeds. Plant Cell Rep 27: 1509-1519.

SEVERINO LS, FERrEIRA GB, MoraES CRA, GONDIM TMS, Freire WSA, CASTRO DA, CARDoso GD AND BELTRÃo NEM. 2006b. Crescimento e produtividade da mamoneira adubada com macronutrientes e micronutrientes. Pesqui Agropecu Bras 41: 563-568.

SEVErino LS, Milani M, Moraes CRA, Gondim TMS AND CARDOSO GD. 2006a. Avaliação da produtividade e teor de óleo de dez genótipos de mamoneira cultivados em altitude inferior a 300 metros. Rev Cienc Agron 37: 188-194.

VAissière BE, Freitas BM AND GEMMILL-HERREN B. 2011. Protocol to detect and assess pollination deficits in crops: a handbook for its use, Rome: FAO, $81 \mathrm{p}$.

VAISSIÈRE BE, Rodet G, COUSIN M, BOTELlA L AND TORRE GROSSA JP. 1996. Pollination effectiveness of honey bees in a kiwifruit orchard. J Econ Entomol 89: 453-461.

VANAJA M, JYOTHI M, RATNAKUMAR P, VAGHEERA P, RAGHURAM REDDY P, JYOTHI LAKSMI N, YADAV SK, MAHESHWARI M AND VENKATESWARLU B. 2008. Growth and yield responses of castor bean (Ricinus communis L.) to two enhanced $\mathrm{CO}_{2}$ levels. Plant Soil Environ 54: 38-46.

VogLer DW AND KALISZ S. 2001. Sex among the flowers: the distribution of plant mating systems. Evolution 55: 202-204.

Waser NM, ChittKa L, Price MV, Williams NM AND OLLERTON J. 1996. Generalization in pollination systems, and why it matters. Ecology 77: 1043-1060.

WeIsS EA. 1971. Castor, sesame and sunflower, London: Leonard Hill, $901 \mathrm{p}$. 